\title{
Pengembangan Media Pembelajaran Interaktif IPA SD Terintegrasi Pendidikan Karakter Peduli Lingkungan
}

\author{
Mawan Akhir Riwanto ${ }^{1}$, Wahyu Nuning Budiarti ${ }^{2}$ \\ mawan.pgsd@unugha.ac.id ${ }^{1}$,wahyununing.pgsd@unugha.ac.id ${ }^{2}$ \\ PGSD, FKIP, UNUGHA Cilacap ${ }^{1}$ \\ PGSD, FKIP, UNUGHA Cilacap ${ }^{2}$
}

\begin{abstract}
Abstrak: Tujuan penelitian ini adalah mengembangkan media pembelajaran interaktif IPA SD yang didalamnya terintegrasi pendidikan karakter peduli lingkungan dan mengetahui kualitas media pembelajaran. Penelitian ini termasuk penelitian pengembangan dengan model dari Borg dan Gall yang menggunakan 10 tahapan dalam prosesnya. Dari penelitian ini dihasilkan media pembelajaran yang berisi materi IPA kelas IV tentang peduli terhadap makhluk hidup. Muatan karakter peduli lingkungan dalam media ini digambarkan melalui ilustrasi animasi tentang urutan kejadian atas perilaku menyimpang terhadap lingkungan hutan, udara, perairan, dan tanah. Kualitas media pembelajaran yang dihasilkan memiliki tingkat kelayakan yang sangat layak setelah mendapatkan validasi dari ahli media (84\%), ahli materi (83\%), dan ahli bahasa (85\%). Hasil angket siswa dan guru pada uji coba operasional menunjukkan nilai $84 \%$ dan $87 \%$ yang merupakan kategori sangat layak sehingga media pembelajaran ini layak untuk di gunakan dalam pembelajaran.
\end{abstract}

Kata kunci: media pembelajaran IPA, karakter peduli lingkungan, media animasi.

\section{DEVELOPMENT OF NATURAL SCIENCES INTERACTIVE LEARNING MEDIA IN ELEMENTARY SCHOOL INTEGRATED WITH ENVIRONMENTAL CARE CHARACTER}

\begin{abstract}
The aims of this study was to develop an interactive learning media for Elementary School Natural Science which integrated character education caring for the environment and knowing the quality of learning media. This research includes development research with a model from Borg and Gall which uses 10 stages in the process. From this research, the resulting learning media containing class IV science material about caring for living things. The content of the character of caring for the environment in this media is illustrated through an animated illustration of the sequence of events for deviant behavior towards forest, air, water and land environments. The quality of the resulting learning media has a very good level of feasibility after getting validation from media experts (84\%), material experts $(83 \%)$, and linguists $(85 \%)$. The results of student and teacher questionnaires on operational trials showed a value of
\end{abstract}


Mawan, Wahyu. Pengembangan media pembelajaran interaktif...

$84 \%$ and $87 \%$ which were very feasible categories so that this learning media was feasible to use in learning.

Keywords: science learning media, environmental care characters, animation media

\section{PENDAHULUAN}

Menteri Perencanaan Pembangunan Nasional Indonesia, Bambang Brodjonegoro dalam Dewi Purningsih (2019) menyatakan bahwa inti dari revolusi industri 4.0 adalah industri yang menitikberatkan pada ramah lingkungan dan sesuai dengan tujuan pengembangan berkelanjutan. Salah satunya memastikan ketersediaan energi tidak lagi bergantung pada bahan bakar fosil. Langkah nyata yang dapat dilakukan untuk mewujudkan hal tersebut diantaranya perilaku masyarakat dalam menjaga ketersediaan sumber daya alam (SDA). Namun kenyataannya masyarakat kurang peduli terhadap keberlangsungan SDA tersebut. Perilaku masyarakat dalam memperlakukan sampah, tanaman, maupun pola konsumstif memberi dampak negatif bagi lingkungan.

Sementara itu menurut pengamat tata kelola perusahaan dan ekologi politik dari Thamrin School of Climate Change and Sustainbility menyebutkan bahwa dalam industri 4.0 semua elemen berupaya meningkatkan dan berpihak pada daya dukung lingkungan. Dari pernyataan tersebut tampak bahwa seluruh elemen masyarakat mempunyai tanggungjawab dalam menyediakan daya dukung lingkungan. Sikap masyarakat yang kurang peduli terhadap ketersediaan SDA (Sumber Daya Alam) merupakan kristalisasi pemahaman, kesadaran, dan kebiasaan masyarakat secara turun-temurun. Perlu adanya pendidikan karakter peduli lingkungan bagi masyarakat diawali dari pendidikan di sekolah dasar (SD). Hasil penelitian Thambusamy \& Elier (2013) serta Lickona (2014) menunjukkan bahwa keberhasilan penerapan pendidikan karakter dapat bersumber dari pembelajaran didalam maupun diluar kelas, hal ini juga didukung oleh Koesoema (2012). Dengan pembentukan karakter sedini mungkin diharapkan dapat menghasilkan generasi muda yang mampu menjaga, melestarikan, dan mengembangkan segala potensi SDA sebagai modal awal keberlangsungan penyediaan daya dukung lingkungan terhadap revolusi industri 4.0 atau selanjutnya.

Permasalahan pendidikan karakter peduli lingkungan bagi siswa SD menurut Ra'id Naufal Husnun (2017) selama ini berada pada faktor internal (guru) dan juga faktor 
Mawan, Wahyu. Pengembangan media pembelajaran interaktif...

eksternal siswa (keluarga dan masyarakat). Permasalahan dari guru berupa tanggungjawab moral dan pemberian contoh/ keteladanan terhadap nilai-nilai peduli lingkungan, permasalahan dari keluarga berupa contoh kebiasaan tidak baik dalam berperilaku terhadap lingkungan secara terus menerus hingga menjadi kebiasaan yang dianggap wajar, sementara dari masyarakat berupa kebiasaan kurang baik yang dilakukan secara bersamasama hingga menjadi sesuatu yang dianggap lazim ketika melihat/ melakukan kegiatan yang merugikan lingkungan.

Dari sisi materi IPA di SD, pengetahuan lingkungan ditekankan pada pengenalan jenis-jenis SDA. Perilaku agar SDA dapat terus digunakan masih sebatas tulisan yang harus dihafal, namun kenyataannya bertentangan dengan kebiasaan di masyarakat. Hal ini menjadikan pembentukan karakter peduli lingkungan menjadi kurang maksimal. Nuansa materi lingkungan yang ada dibuku masih menyatakan kondisi alam kita baik-baik saja tanpa memberikan gambaran rangkaian peristiwa yang akan mengikuti perilaku tidak peduli terhadap lingkungan. Sebagai contoh, kebiasaan siswa mengkonsumsi minuman instan yang jika dianalisis lebih lanjut akan memberikan dampak negatif pada lingkungan. Salah satunya petani teh sulit menjual produknya dan akan mengganti jenis tanamannya dengan yang lebih menguntungkan. Dengan sedikitnya tanaman teh di dataran tinggi, yang merupakan tanaman penahan erosi, menjadikan bencana tanah longsor. Dampak akhirnya adalah pemberian daya dukung lingkungan dalam pengadaan sumber energi alternatif menjadi terhambat. Dari uraian di atas maka tujuan dalam peneliti ini adalah mengembangkan media pembelajaran interaktif IPA SD terintegrasi karakter peduli lingkungan. Media pembelajaran hasil pengembangan ini digunakan sebagai pendamping penyampaian materi kelas IV Tema peduli terhadap makhluk hidup.

Media interaktif yang dikembangkan dalam penelitian menggunakan animasi gambar gerak dan disajikan dalam nuansa yang menyenangkan. Hal ini sejalan dengan ulasan Rahmatina et al (2019) tentang media animasi yaitu media ini memainkan peran penting dalam proses meningkatkan hasil belajar. Animasi merupakan produk ilusi gerak yang mampu nyajikan informasi dalam bentuk hiburan. Multimedia interaktif meniurut Lukman et al (2018) didesain untuk mendukung pembelajaran mandiri. Salah satu keunggulan pemanfaatan teknologi komputer untuk mengembangkan media pembelajaran menurut Zamani dan Heru (2016) adalah lebih inovatif dan interaktif. Hal inilah yang menyebabkan media animasi dapat memotivasi siswa dan meningkatkan 
Mawan, Wahyu. Pengembangan media pembelajaran interaktif...

sikap positif siswa. Lebih lanjut lagi dijelaskan bahwa anak sekolah dasar lebih menyukai belajar sambil bermain dan ini didukung oleh penggunaan media animasi.

\section{METODE}

Penelitian ini merupakan penelitian jenis riset dan pengambangan yang dilakukan dari bulan Juni-September 2020. Adapun model penelitian pengembangan yang menjadi acuan adalah model Borg and Gall. Mawan (2018) menyebutkan terdapat 10 tahapan pelaksanaan penelitian pengembangan model Brog and Gall yaitu pengumpulan informasi, perencanaan pengembangan, pengembangan produk awal, pengujicobaan awal di lapangan, perbaikan produk utama, uji coba utama di lapangan, revisi operasional, uji coba operasional, perbaikan akhir produk, diseminasi dan penerapan.

Penelitan ini diawali dengan pengumpulan informasi berupa studi lapangan yaitu menganalisis kurikulum sekolah dasar yang sedang diterapkan, analisis ketersediaan sumber belajar di lapangan, analisis kebiasaan negatif masyarakat terhadap lingkungan, analisis urutan dampak negatif masyarakat terhadap lingkungan. Selanjutnya dilakukan studi pustaka mengenai teori yang berhubungan dengan teori-teori media pembelajaran interaktif IPA, karakter peduli lingkungan, analisis animasi pembentuk karakter peduli lingkungan dan mengkaji temuan-temuan penelitian terbaru yang relevan.

Tahapan ke dua yaitu pembuatan bagan kerangka isi media pembelajaran yang akan dikembangkan. Hasil dari tahapan perencanaan ini kemudian dilakukan pengembangan produk awal dimana hasil pengembangan media pembelajaran ini divalidasi oleh ahli media, bahasa, dan materi untuk mendapatkan penilaian dan saran untuk penyempurnaan. Selanjutnya dilakukan tahapan uji coba skala kecil yang melibatkan 3 siswa SD dan 1 orang guru yang dilakukan secara daring. Hasil penilaian dari siswa dan guru ini dijadikan sebagai dasar perbaikan media pembelajaran yan dikembangkan dari sudut pandang pengguna.

Tahapan berikutnya adalah uji coba utama yang melibatkan 1 kelas dalam 1 sekolah (berbeda dengan sekolah yang digunakan untuk ujicoba produk awal) dengan tujuan untuk mengetahui apakah masih ada kekurangan terhadap produk. Selanjutnya jika masih terdapat kekurangan maka dilakukan perbaikan dan penyempurnaan. Tahapan berikutnya adalah uji coba operasional. Pada tahap ini peneliti dibantu anggota 
Mawan, Wahyu. Pengembangan media pembelajaran interaktif... peneliti dalam uji coba operasional dengan melibatkan 2 sekolah di kabupaten Cilacap dan Banyumas secara daring. Dari hasil uji coba ini dilakukan perbaikan jika terdapat kendala penggunaan media pembelajaran yang dikembangkan. Tahapan terakhir adalah deseminasi dan penerapan. Pada tahap ini dilakukan pendistribusian media ke SD di Kabupaten Banyumas dan Cilacap. Menurut Winna dan Dini (2019) pengembangan media pembelajaran interaktif diperlukan perancangan flowchart agar pengelolaan tiap halaman yang akan dibuat terstruktur dan terencana dengan baik. Adapun kerangka media/ flowchart dalam penelitian ini adalah sebagai berikut :

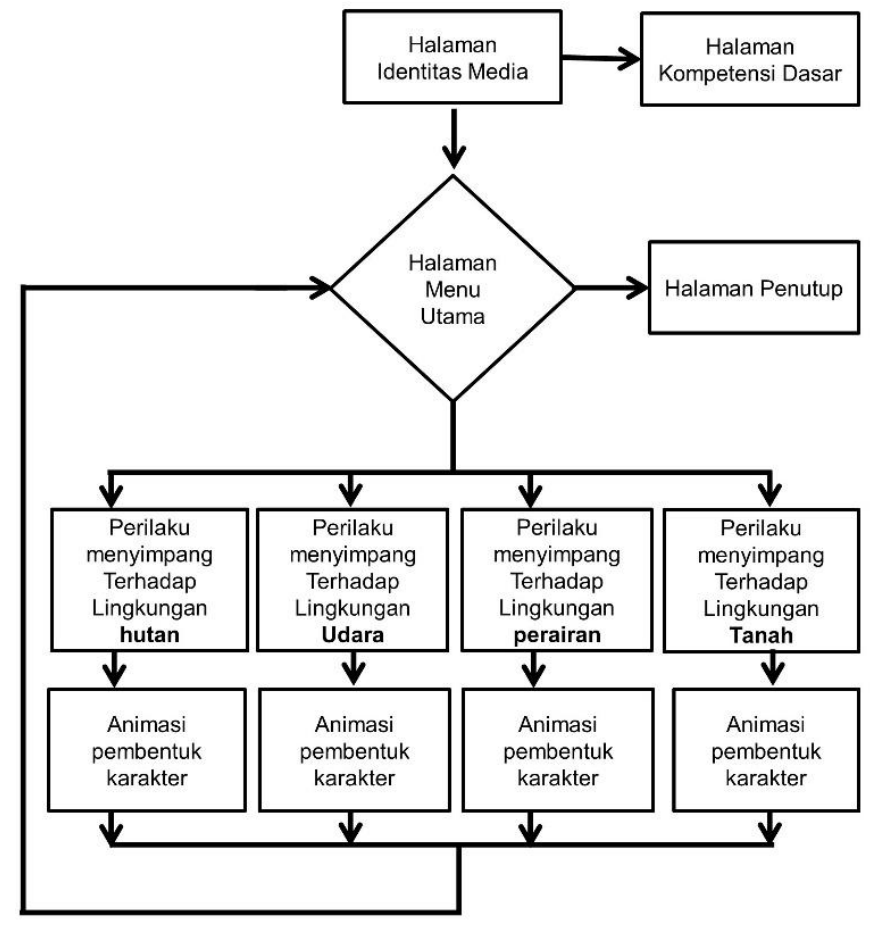

Gambar 1. Kerangka Isi Media

Subjek penelitian ini adalah guru kelas IV, siswa kelas IV, ahli media, ahli bahasa, dan ahli materi. Sekolah yang dilibatkan adalah SD baik negeri maupun swasta yang berada di Kabupaten Cilacap dan Banyumas.

Analisis data dalam peneliti ini meliputi : analisis data kuantitatif berupa angket penilaian validasi ahli, penilaian guru, dan penilaian siswa kemudian dikonversi ke dalam penilaian kualitatif untuk mendapatkan kriteria kualitas media. Rujukan kelayakan yang digunakan mengacu pada Tabel 1 berikut ini :

Tabel 1. Hasil Analisis Kompetensi Dasar

\begin{tabular}{|c|c|c|}
\hline No & Skor dalam persen $(\%)$ & Kategori Kelayakan \\
\hline 1 & $<21$ & Sangat Tidak Layak \\
\hline
\end{tabular}


Mawan, Wahyu. Pengembangan media pembelajaran interaktif...

\begin{tabular}{|c|c|c|}
\hline 2 & $21-40$ & Tidak layak \\
\hline 3 & $41-60$ & Cukup Layak \\
\hline 4 & $61-80$ & Layak \\
\hline 5 & $81-100$ & Sangat Layak \\
\hline
\end{tabular}

Sumber: (Iis \& Totok, 2017)

HASIL

Hasil analisis kompetensi dasar yang diharapkan muncul pada siswa disajikan dalam Tabel 2 berikut:

Tabel 2. Hasil Analisis Kompetensi Dasar

\begin{tabular}{|c|c|c|}
\hline No & Kompetensi Dasar & Indikator Kompetensi Dasar \\
\hline \multirow[t]{6}{*}{1} & \multirow{6}{*}{$\begin{array}{l}\text { Memahami pentingnya r upaya } \\
\text { keseimbangan dan pelestarian sumber daya } \\
\text { alam di lingkungannya }\end{array}$} & $\begin{array}{l}\text { Mengidentifikasi pentingnya keseimbangan alam dan } \\
\text { kelestarian sumber daya alam }\end{array}$ \\
\hline & & $\begin{array}{l}\text { Mengidentifikasi pentingnya menjaga keseimbangan } \\
\text { dan sumber daya alam di lingkungan sekitar }\end{array}$ \\
\hline & & $\begin{array}{l}\text { Mengidentifikasi dampak pemanfaatan teknologi } \\
\text { bagi keseimbangan alam dan kelestarian sumber } \\
\text { daya alam }\end{array}$ \\
\hline & & $\begin{array}{l}\text { Mengidentifikasi pentingnya } \\
\text { penggunaan sumber daya alam sebagai langkah } \\
\text { pelestarian sumber daya alam. }\end{array}$ \\
\hline & & $\begin{array}{l}\text { Mengidentifikasi dampak pemanfaatan sumber daya } \\
\text { alam yang tidak terkontrol }\end{array}$ \\
\hline & & $\begin{array}{l}\text { Mengidentifikasi pentingnya pemanfaatan barang } \\
\text { bekas sebagai usaha pelestarian sumber daya alam }\end{array}$ \\
\hline \multirow[t]{6}{*}{2} & \multirow{6}{*}{$\begin{array}{l}\text { Melakukan kegiatan upaya pelestarian } \\
\text { sumber daya alam bersama orang-orang di } \\
\text { lingkungannya }\end{array}$} & $\begin{array}{l}\text { Memberikan contoh kegiatan menjaga kelestarian } \\
\text { sumber daya alam }\end{array}$ \\
\hline & & $\begin{array}{l}\text { Mempraktikkan pelestarian sumber daya alam di } \\
\text { lingkungan sekitar }\end{array}$ \\
\hline & & $\begin{array}{l}\text { Memberikan contoh pemanfaatan teknologi yang } \\
\text { ramah lingkungan bagi kelestarian sumber daya alam }\end{array}$ \\
\hline & & $\begin{array}{l}\text { Mempraktikkan pembatasan penggunaan sumber } \\
\text { daya alam dalam kehidupan sehari-hari }\end{array}$ \\
\hline & & $\begin{array}{l}\text { Memberikan tulisan kegiatan pencegahan } \\
\text { berkurangnya sumber daya alam dalam kehidupan } \\
\text { sehari-hari }\end{array}$ \\
\hline & & $\begin{array}{l}\text { Mengomunikasikan contoh kegiatan pemanfaatan } \\
\text { sampah sebagai upaya pelestarian sumber daya alam }\end{array}$ \\
\hline
\end{tabular}

Hasil pengolahan angket validasi ahli disajikan dalam Tabel 3 berikut:

Tabel 3. Hasil Validasi Ahli

\begin{tabular}{|c|c|c|c|}
\hline No & Ahli & Skor dalam persen (\%) & Kategori Kelayakan \\
\hline 1 & Ahli Media & 84 & Sangat Layak \\
\hline 2 & Ahli Materi & 83 & Sangat Layak \\
\hline 3 & Ahli Bahasa & 85 & Sangat Layak \\
\hline
\end{tabular}

Hasil pengolahan angket validasi ahli disajikan dalam Tabel 4 berikut: 
Mawan, Wahyu. Pengembangan media pembelajaran interaktif...

Tabel 4. Hasil Angket Guru

\begin{tabular}{|c|l|c|c|}
\hline No & \multicolumn{1}{|c|}{ Trial } & Score Appraisal (\%) & Kategori Kelayakan \\
\hline 1 & Uji Coba awal & 86 & Sangat Layak \\
\hline 2 & Uji Coba Utama & 84 & Sangat Layak \\
\hline 3 & Uji Coba Operasional & 87 & Sangat Layak \\
\hline
\end{tabular}

Hasil pengolahan angket validasi ahli disajikan dalam Tabel 5 berikut:

Tabel 5. Hasil Angket Siswa

\begin{tabular}{|c|l|c|c|}
\hline No & \multicolumn{1}{|c|}{ Trial } & Score Appraisal (\%) & Kategori Kelayakan \\
\hline 1 & Uji Coba awal & 82 & Sangat Layak \\
\hline 2 & Uji Coba Utama & 84 & Sangat Layak \\
\hline 3 & Uji Coba Operasional & 84 & Sangat Layak \\
\hline
\end{tabular}

\section{PEMBAHASAN}

Penelitian ini menggunakan tahapan-tahapan penelitian pengembangan dengan 10 kegiatan. Diawali dengan proses research and information collecting yaitu pengmpulan informasi tentang kebutuhan media pembelajaran IPA kelas IV serta pentingnya pendidikan karakter peduli terhadap lingkungan untuk disisipkan kedalam pembelajaran. Pertimbangan dalam pengembangan media ini selain dari sisi kompetensi dasar juga dari aspek kebutuhan siswa akan media pembelajaran. Sulthon (2016) menyatakan bahwa belajar IPA harus mengalami proses ilmiah, mampu menghasilkan produk dari pelaksanaan percobaan, serta terbentuknya sikap ilmiah. Belajar IPA tidak dapat dilaksanakan dengan cara menghafal dan mendengarkan guru saja, tetapi melalui praktikum, pengamatan, maupun berkreasi dalam percobaan sehingga memunculkan karakter menjada dan mau memperbaiki gejala alam yang terjadi serta pada akhirnya dapat menjaga stabilitas alam. Pernyataan tersebut mendukung pemilihan konsep kepedulian lingkungan dalam IPA yang diwujudkan dalam pengamatan media interaktif sehingga memunculkan sikap ilmiah yang diharapkan nantinya akan membentuk karakter peka terhadap lingkungan.

Dari tahapan ini juga diketahui bahwa generasi sekarang sudah mulai memudar tingkat kepeduliannya terhadap lingkungan. Hal ini dapat dilihat dari ketidakpedualian siswa terhadap lingkungannya. Mulai dari jajan sembarangan, membuang dan memperlakukan sampah dengan sembarangan, mengotori sumber perairan. Hasil penelitian dari Husnul dkk (2019) menunjukkan beberapa contoh perilaku ketidakpedulian siswa terhadap lingkungan diantaranya masih banyak siswa yang 
Mawan, Wahyu. Pengembangan media pembelajaran interaktif... membuang sampah sembarangan seperti membuang rautan pensil dan plastik makanan di dalam laci, selain itu masih banyak pula siswa yang memetik tanaman di lingkungan sekolah untuk bermain. Dini Palupi Putri (2018) mengemukakan bahwa aktifitas yang dilakukan secara terus menerus dan berulang akan membentuk suatu kebiasaan dan pada akhirnya membentuk sebuah karakter. Sementara itu salah satu peran pendidikan karakter dalam pendidikan yang disebutkan oleh Daryanto dan Darmiatun Suryatri (2013) yaitu pembinaan watak diantaranya mengubah kebiasaan buruk atau mengubah kebiasaan senang tetapi jelek.

Russell \& Waters (2014) mengemukakan bahwa pendidikan karakter membantu siswa dalam menganalisis dan menafsirkan lingkungan sekitarnya. Hal serupa juga diutarakan oleh Engkizar dan Fuady (2016) yaitu pendidikan karakter mengantarkan siswa mempunyai kepribadian dan nilai-nilai karakter mulia. Pemikiran siswa terhadap dampak perilaku sehari-hari yang mereka lakukan terhadap kelestarian lingkungan sekitarnya sangat minim. Daryanto dan Darmiatun (2013) mendefinisikan segala upaya elemen sekolah, orang tua, dan anggota masyarakat dalam rangka membantu anak-anak hingga remaja agar bersifat peduli, berpendirian, serta memiliki rasa tanggung jawab sebagai pengertian dari pendidikan karakter. Berdasarkan pengertian tersebut tampak bahwa pendidikan karakter tidak hanya menjadi tanggung jawab pihak sekolah melainkan juga keluarga dan masyarakat. Hal senada juga dikemukakan Akhwani (2019) dalam penelitiannya dimana diuraikan bahwa pembelajaran harus menyesuaikan dengan jaman. Mendidik etika akan lebih baik dilakukan sedini mungkin. Purwanti (2017) juga mendukung penumbuhan karakter peduli lingkungan sedini mungkin pada siswa sehingga nantinya mampu secara bijak dan bertanggung jawab mengelola sumber daya alam di sekitarnya demi keberlangsungan generasi mendatang.

Sementara itu dari hasil analisis silabus SD kelas IV, diperoleh hasil kompetensi dasar yang erat kaitannya dengan pelestarian sumber daya alam adalah memahami pentingnya upaya keseimbangan dan pelestarian sumber daya alam di lingkungannya untuk kompetensi pengetahuan dan melakukan kegiatan upaya pelestarian sumber daya alam bersama orang-orang di lingkungannya untuk kompetensi dasar keterampilan.

Tahapan kedua yang dilakukan dalam penelitian ini adalah planning. Pada tahapan ini peneliti melakukan perencanaan pengembangan yang diawali dengan pembuatan rancangan isi media. Selanjutnya masuk ke tahap develop preliminary form 
Mawan, Wahyu. Pengembangan media pembelajaran interaktif...

of product dimana rancangan media yang telah disusun diproses dengan menggunakan software Adobe Flash CS6. Output dapi tahapan ini adalah media pembelajaran berformat executable (.exe) yang dapat diputar di perangkat dengan sistem operasi windows tanpa melakukan instalasi software tambahan yang lain. Andi Pramono dalam Farida, dkk (2016: 2-3) menjelaskan alasan memilih adobe flash sebagai media presentasi diantaranya hasil akhir file memiliki ukuran yang lebih kecil setelah dipublish, mampu mengimpor hampir semua file gambar dan audio, animasi dapat dibentuk, dijalankan, dan dikontrol, dapat membentuk file executable (*.exe) sehingga dapat dijalankan pada semua komputer tanpa harus menginstal program flash.

Media pembelajaran yang telah dikembangkan pada tahapan sebelumnya kemudian divalidasi oleh ahli materi, ahli media, dan ahli bahasa. Adapun instrumen validasi ahli media meliputi relevansi, keakuratan, kelengkapan sajian, konsep dasar materi, kesesuaian dengan tuntutan pembelajaran. Tahapan preliminary field testing dilaksanakan dengan meminta penilaian media yang dikembangkan pada ahli media, ahli materi, dan ahli bahasa, serta diujicobakan pada 1 guru dan 3 siswa. Penilaian dari ahli materi mendapatkan skor $83 \%$ dan masuk ke dalam kriteria sangat layak. Saran dari ahli materi adalah perlu adanya penegasan konsep dalam media agar selain pendidikan karakternya dapat diterima, kompetensi yang disampaikan juga tetap dapat dikuasai oleh siswa. Sementara itu ahli media memberikan total skor $84 \%$ yang juga masuk dalam kategori sangat layak. Saran dari ahli media adalah dalam hal tata letak objek agar terlihat seimpang pada layar. Ahli bahasa memberikan hasil validasi dengan skor $85 \%$ dengan kriteria sangat layak dan tanpa memberikan catatan perbaikan. Sementara itu hasil angket guru pada tahap ini menunjukkan skor $86 \%$ (sangat layak) dan skor $85 \%$ dari siswa dengan kriteria yang sama. Selanjutnya dilakukan tahap main product revision dengan cara memperbaiki sesuai saran dari ahli.

Tahapan uji coba utama atau main filed testing dilakukan pada 1 guru dan satu kelas. Hasilnya menunjukkan skor $84 \%$ baik dari angket guru maupun angket siswa dimana kriteria yang diperoleh dari media ini adalah sangat layak. Selanjutnya dilaksanakan tahapan operasional product revision berdasarkan hasil angket. Tahapan opreasional filed testing dilaksanakan di 2 sekolah dasar dan hasilnya adalah skor $87 \%$ dari guru dan $84 \%$ dari siswa sehingga masih tetap berada pada kategori sangat layak. Tahapan final product revision dilaksanakan untuk memperbaiki kekurangan 
Mawan, Wahyu. Pengembangan media pembelajaran interaktif...

berdasarkan angket pada uji coba utama. Selanjutnya dissemination and implementation dilakukan melalui pendistribusian media pembelajaran yang telah dikembangkan dalam hal ini diberikan ke sekolah dasar di kabupaten Banyumas dan Cilacap Jawa Tengah.

\section{SIMPULAN}

Dari penelitian pengembangan ini dihasilkan media pembelajaran interaktif IPA SD terintegrasi pendidikan karakter peduli lingkungan yang layak digunakan sebagai media pembelajaran kelas IV tema peduli terhadap makhluk hidup. Dalam media pembelajaran ini berisi materi IPA tentang sumber daya alam dan pelestariaanya. Tindak lanjut yang akan dilaksanakan dari hasil penelitian ini adalah pengujian efektifitas penggunaan media pembelajaran di pelaksanaan pembelajaran.

\section{UCAPAN TERIMA KASIH}

Terimakasih kepada Kementerian Riset dan Teknologi / Badan Riset dan Inovasi Nasional yang telah mendanai penelitian ini dalam hibah Penelitian Dosen Pemula, Universitas Nahdlatul Ulama Al Ghazali Cilacap yang telah memberikan dukungan penuh terhadap pelaksanaan penelitian ini, dan semua pihat yang membantu terselesaikannya penelitian ini.

\section{DAFTAR RUJUKAN}

Akhwani. (2019). Strategy Of Digital Etiquette Education of Elementary School Students. Primaryedu (Journal of Elementary Education) Volume 3, Number 2, September 2019. P-ISSN: 2580-9326 E-ISSN: 2580-7714

Daryanto dan Darmiatun. (2013). Implementasi Pendidikan Karakter di Sekolah. Yogyakarta: Gava Media

Dini Palupi Putri. (2000). Pendidikan Karakter Pada Anak Sekolah Dasar di Era Digital. AR-RIAYAH : Jurnal Pendidikan Dasar, Vol. 2, No.1, p ISSN 2580362X; e ISSN 2580-3611.

Doni Koesoema A. (2007). Pendidikan Karakter Strategi Mendidik Anak di Zaman Global. Jakarta: Grasindo.

Engkizar Murniyetti dan Fuady Anwar. (2019). Pola Pelaksanaan Pendidikan Karakter Terhadap Siswa Sekolah Dasar. Jurnal Pendidikan Karakter, Vol.6, No. 2.

Ernawati, I and T. Sukardiyomo, "Uji Kelayakan Media Pembelajaran Interaktif Pada Mata Pelajaran Administrasi Server," Elinvo (Electroocs, Informatics, and Vocational Education), vol. 2, no. 2, 2017. 
Mawan, Wahyu. Pengembangan media pembelajaran interaktif...

Farida, dkk. (2016). Pengembangan Media Pembelajaran Menggunakan Adobe Flash untuk Meningkatkan Hasil Belajar PKn. Jurnal Kreatif, Vol 7, Nomor 1, September 2016, Hal 1-10. ISSN: 2580-6904.

Husnul Khotimah, dkk. (2019). Improved of The Environment Care Attitude on Science Learning by Applying the Science Environment Technology And Society (SETS) Model. SHEs: Conference Series 1 (1) (2018) 353-359.

Husnun, R. N. (2017). Pendidikan Karakter Peduli Lingkungan dalam Proses Pembelajaran di SD Alam Harapan Kita Kabupaten Klaten. Skripsi. Universitas Muhammadiyah Surakarta, Surakarta.

Lickona, Thomas. (2014). Educating for Character. Journal of Moral Education, Vol. 13, No. 3.

Lukman Arief Novianto, I Nyoman Sudana Degeng, Agus Wedi. (2018). Pengembangan Multimedia Interaktif Mata Pelajaran IPA Pokok Bahasan Sistem Peredaran Darah Manusia Untuk Kelas VIII SMP Wahid Hasyim Malang. JKTP: Jurnal Kajian Teknologi Pendidikan, Vol. 1, No. 3.

Purningsih, D. (2019). Revolusi Industri 4.0 Menjadi Tantangan Kelestarian Lingkungan Hidup. https://www.greeners.co/berita/revolusi-industri-4-0menjadi-tantangan-kelestarian-lingkungan-hidup/ diakses pada 8 Agustus 2019

Purwanti, D. (2017). Pendidikan Karakter Peduli Lingkungan dan Implementasinya. WIJACENDEKIA Jurnal Riset Pedagogik, Vol 1, Nomor 2, Desember 2017, Hal 14-20. e-ISSN 2581-1835.

Rahmatina et al. (2019). Jigsaw Using Animation Media for Elementary School. Journal of Physics: Conference Series, 1424 (2019) 012027.

Riwanto, M. A. (2018). Pengembangan Media Pembelajaran IPA Interaktif Berbasis Keterampilan Proses Sains untuk Kelas Atas Sekolah Dasar. Jurnal Pancar, Vol 2, Nomor 2, November 2018, hal 12-15. e-ISSN : 2550-0619.

Roslind, Thambusamy \& Adzura, A. Elier. (2013). Shaping the Bamboo From the Shoot: Elementary Level Character Education in Malaysia. Journal Childhood Education, Vol. 89, No. 6.

Sulthon. (2016). Pembelajaran IPA yang Efektif dan Menyenangkan Bagi Siswa Madrasah Ibtidaiyah (MI). Jurnal Elementary Vol. 4, No. 1, Januari-Juni 2016. Hal 38-54. e- ISSN: 2503-0256.

William B. Russell III \& Stewart Waters. (2014). Developing Character in Middle School Students: A Cinematic Approach. The Clearing House: A Journal of Educational Strategies Issues and Ideas, 87:4, 161-167, DOI: 10.1080/00098655.2014.888046

Winna Dharmayanti dan Dini Oktarika. (2019). Pengembangan Media Pembelajaran Berbasis Multimedia Interaktif Untuk Guru IPA di Sekolah Menengah Pertama. Jurnal Pendidikan Informatika dan Sains, Vol. 8, No. 1, P-ISSN: 2089-2802, EISSN: 2407-1536, DOI:10.31571/saintek.v8i1.1156. 
Mawan, Wahyu. Pengembangan media pembelajaran interaktif...

Zamani, A. Z \& Heru, N. (2016). Pengembangan Media Pembelajaran Berbantuan Komputer Untuk Meningkatkan Motivasi dan Hasil Belajar. Jurnal Pendidikan Matematika dan Sains, Vol. 4, No.1. 